класичного університету в органічній єдності мотиваційно-ціннісного, художньо-спортивного й творчо-діяльнісного компонентів. Перспективи подальших досліджень. Перспективи подальшої роботи будуть спрямовані на дослідження та аналіз результатів упровадження експериментальної програми в процес фізичного виховання класичного університету для формування естетико-фізичних якостей студентів.

\title{
Література:
}

1. Бутенко М.В. Формирование культуры здорового образа жизни личности студента в процессе занятий атлетической гимнастикой : автореф. дисс. ... канд. пед. наук : 13.00.04. Б. : 2004. 22 с.

2. Про фізичну культуру i спорт : Закон України. Відомості Верховної Ради України (BBP). 1994. № 14. URL: zakon2.rada.gov.ua/ laws/ show/3808-12.

3. Корж Н.Л. Формування ціннісного ставлення у студентів до фізичної культури в процесі самостійних занять : автореф. дис. ... канд. наук 3 фіз. вих. і спорту : 24.00.02. Д., 2016. 21 с.

DOI https://doi.org/10.30525/978-9934-588-80-8-2.36

\section{USING A QUEST ROOM TO CREATE NATURAL COMMUNICATION CONDITIONS FOR TEACHING ENGLISH TO FOREIGN ARCHITECTURE STUDENTS}

\author{
Dragomyretska O. O. \\ Senior Lecturer at the Language Department \\ of the Training Center for Foreign Students \\ Odessa State Academy of Civil Engineering and Architecture \\ Odessa, Ukraine
}

Foreign university students in Ukraine have the possibility to study in English. This program exists for foreign non-native English speakers who have mastered English sufficiently to enter university. To promote the students' further development of their language skills, new methods for teaching English to foreigners who study and live in non-English environments are needed. Thus, a made-up language environment is needed to train student language skills. In the last five years, quest rooms (also known as escape rooms and reality quests) have become a popular new fun activity among youth. The aim of escape game is uniting a team through a common 
goal. For escape game players (participants), the target is to catch new information, understand it and found where and how they can use it. To learn efficiently, students should be motivated, be ready to accept to make mistakes and stimulate different channels of getting information. So, the escape game creates the perfect environment where those skills can be trained.

The aim of the abstract is to show how the quest can contribute to development of the environment required to provide natural communication for teaching English to foreign architecture students.

The implementation of quests and other interactive technologies in education has been studied by following scientists: Kicherova M.N., Efimova G.Z. [2], Bezrodnikh T.V. [1], Sokol I.M. [5], Malinovskaya M.P. [3], Mezentseva M.E. [4] and others.

The Language Department of the Training Center for Foreign Students at the Odessa State Academy of Civil Engineering and Architecture has developed a number of tutorials and scripts for creating quest rooms for $3^{\text {rd }}$ year foreign students of the architectural faculty. In order to inhibit fear and apprehension of students to the learning process, the game aspect is a key point. A script takes an important part in the development of a quest. Students must have fun, open their mind to the information and forget that they are at studies. It is especially efficient for technical mind-oriented students who can be unconfident regarding their own availability to learn new language. Using new available technologies, like 3D printer and applications on smartphones, special tutorials were created in order to propose various ways to help to improve students' skills (visual and audio comprehension, reading, writing, physical manipulation, etc.). Thereby, tutorials include: oral and written skills production-oriented tasks, understanding-oriented tasks, and tasks for vocabulary and grammar perfection. Moreover, watching students collecting and using information while solving tasks, a teacher is able to identify students' contribution, their knowledge of a subject and make evaluation of the students' language skills at the same time. Thus, an escape room becomes a way to learn and a way to evaluate without stress of the examination. In using these tutorials during the educational process, students have shown an enhanced interest in the language and improvement of understanding the language. Scripts allow to adopt each students' need, a level of difficulties in tasks can follow the progress of the participant. Also, it shows to students that learning can be as fun as useful. In turn, it has improved their understanding of educational materials for their main educational specialty (Architecture).

Thus, implementing the quest as a learning language technology in higher education can help students to study at the environment required to provide natural communication for teaching English to foreign architecture students. 


\title{
References:
}

1. Bezrodnikh T.V. (2016) Interactive technologies at universities - the technologies of building student's social and pedagogical competences. Problems of modern pedagogical education. № 52-5. P. 58-65. (in Russian)

2. Kicherova M.N., Efimova G.Z. (2016) Educational quests as a creative educational technology for students of the new generation. Internet-magazine "World of science», volume 4, number $5 \mathrm{P}$. 1-10 http://mir-nauki.com/PDF/28PDMN516.pdf (in Russian)

3. Malinovskaya M.P. (2017) Educational quest in student's professional competences building in pedagogical university. International scientific magazine» Symbol of science». № 04-2. P. 164-170 (in Russian)

4. Mezientzeva M.E.(2017) Quest as a modern method of active methods of teaching foreign languages. Questions of methodology ofteaching at universities. V. 6. №21. P. 75-83. DOI: 10/18720/HUM/ISSN 22278591.21.8 (in Russian)

5. Sokol I.M. (2014) Classification quests. Young scientist № 6 (09) June. P. 138-140 http://molodyvcheny.in.ua/files/journal/2014/6/89.pdf. (in Russian)

DOI https://doi.org/10.30525/978-9934-588-80-8-2.37

\section{INTEGRATING ESSENTIAL SOFT SKILLS IN TEACHING ENGLISH TO LAW STUDENTS}

\author{
Zhyhadlo O. Yu. \\ Candidate of Philological Sciences, \\ Lecturer at the Foreign Languages Department, Law School \\ Taras Shevchenko National University of Kyiv \\ Kyiv, Ukraine
}

Teaching has always been a challenging task requiring maximum effort and involvement on behalf of the instructor. However, teaching in the $21^{\text {st }}$ century is even more challenging since the teacher is expected to focus not only on giving knowledge of the subject, but also on a scope of other issues a contemporary society faces. Due to rapid technology advances, quick and easy access to information, changes in the labour market, students have to cope with new challenges and face many non-academic requirements in order to meet volatile employment standards which are often at variance with what they have been taught at school and university. It appears thus to be the teacher's task to boost students' adaptability, communication skills, 